\title{
Design of Irrigation Network of the IGKV Farm, Raipur, Chhattisgarh, India
}

\author{
N. K. Thakur ${ }^{1}$, D. Khalkho ${ }^{1}$, P. Katre ${ }^{1}$, P. K. Jamrey ${ }^{2 *}$ and R. K. Mishra ${ }^{3}$ \\ ${ }^{1}$ Department of Soil and Water Engineering, SV College of Agricultural Engineering and \\ Technology \& Research Station Faculty of Agricultural Engineering Indira Gandhi Krishi \\ Vishwavidyalaya Raipur, India \\ ${ }^{2}$ Krishi Vigyan Kendra, IGKV, Gariyaband (C.G.), India \\ ${ }^{3}$ Department of Agriculture Development and FWBT, Government of Chhatisgarh, India \\ *Corresponding author
}

\section{A B S T R A C T}

\section{Keywords}

Irrigation,

Kharif period,

Capacity, Water

level

Article Info

Accepted:

15 April 2020

Available Online:

10 May 2020
4 Lift Irrigation Schemes (LIS) were proposed in the study to utilize the available flows in the rivulet during Kharif period and also during the initial phase of Rabi crop. Besides this surface water utilization was proposed to be increased by repair and maintenance of the existing diversion canal of Bharri Dam. Peak carrying capacity of the diversion canal was worked out to be $85 \mathrm{lps}$ and the irrigation command of it is 32.5 ha. It was found that there are 42 no. of bore wells in which 32 is working and 10 bore wells is not working. The average discharge and water level fluctuation for 5 year period was found to be $5.8 \mathrm{lps}$ and $12.35 \mathrm{~m}$ respectively. The potential of water resources was estimated. The available surface water and ground water during study period was found $0.71 \mathrm{MCM}$ and $0.50 \mathrm{MCM}$.

\section{Introduction}

Water is the most precious gift of nature. Irrigation is the artificial application of water to land. Some land requires irrigation or drainage before it is possible to use it for any agricultural production; other land profits from either practice to increase production.
Some land of course does not need either. Although both practice may be and both often are used for non-agricultural purposes to improve the environment, this article is limited to their application to agriculture. Water productivity can be improved by choosing well-adapted crop types, reducing unproductive water losses and maintaining 
healthy, growing crops through optimized water, nutrient, agronomic management, irrigation and drainage plan.

In general, improving agricultural water productivity, thus freeing up water for ecosystem functions, can be achieved by creating synergies across scales and between various agricultural sectors and the environment, and by enabling multiple uses of water and equitable access to water resources for different groups in society. This applies to the Irrigation and drainage network systems in India. This paper presents definition, measurement and practical application of water productivity. It is also widely accepted fact that there is no substitute for irrigated agriculture in terms of its production volume and drainage has a role to play here

\section{Materials and Methods}

\section{Study area}

Raipur district in located under the agroclimatic zone "Chhattisgarh plains" in the state of Chhattisgarh. The study area (IGKV farm Raipur) is situated $7 \mathrm{~km}$ away from Raipur district on Mahasamund road. The IGKV Raipur situated in $81^{\circ} 41^{\prime} 20^{\prime \prime}$ to 81 ${ }^{\circ} 43^{\prime} 15^{\prime \prime}$ E longitude $21^{\circ} 13^{\prime} 35^{\prime \prime}$ to $21^{\circ} 14^{\prime} 15^{\prime \prime}$ $\mathrm{N}$ Latitude at elevation is 285-295 meter (MSL) and area of IGKV is 200 ha and Climate is Sub-tropical, annual rainfall recorded (yearly) $1064.7 \mathrm{~mm}$. The exact location of study site is depicted in Fig. 1.

\section{Agro climate}

Chhattisgarh state has been divided into three Agro-climate zones namely Chhattisgarh plains, Baster Plateau and Northern hill zone covering $51.0 \%, 28.0 \%$ and $21.0 \%$ of the geographical area, respectively as per NARP classification. Chhattisgarh plain is the largest agro-climatic zone of the state covering 16 districts out of 27. The climate is sub-tropical characterized by extreme summer from March to May the study area comes under subtropical type of climate. Due to high rainfall and proximity to Eastern coast the climate remains sub humid for about five months. On the basis of rainfall and temperature the year may be divided into three distinct season's namely rainy season from June to October, winter season from November to February and summer season from March to June.

\section{Land use and cropping pattern}

The total area of IGKV farm Raipur where study was conducted was 200 ha. The gross cropped area in IGKV farm Raipur was 136 ha which $68 \%$ of the total geographical area. The net sown cropped area was 117 ha which $58.5 \%$ of the total geographical area. Area sown more than once area was 115 ha which $57.5 \%$ of the total geographical area. During Kharif season crops were grown in 95 ha and in $R a b i$ season crops were grown in 89 ha only.

\section{Recharge from rainfall}

For the purpose of recharge assessment using water level fluctuation method the monsoon season may be taken as May/June to October/November for all areas. Due to less demand for groundwater in view of adequate moisture in the soils, the resources available during this period are not fully utilized. Therefore it is 38 recommended that the groundwater recharge may be estimated on pre-monsoon (May/June) to post-monsoon (October/November). This is the dynamic groundwater which is available for us. Here groundwater recharge is estimated by using water level fluctuation method. Adequate data on groundwater level fluctuation were collected from Central Ground Water Board, (NCCR) Raipur. The change in storage was computed from the following equation: 
$\mathrm{S}=\mathrm{A} X \mathrm{X} X \mathrm{Sy}$

Where, $\mathrm{S}=$ change in storage $\mathrm{m}^{3}$

$\mathrm{A}=$ area of the site (ha)

$\mathrm{h}=$ change in water level $(\mathrm{m})$

$\mathrm{Sy}=$ specific yield

The geological formation of the study area is limestone dolomite. The value of specific yield recommended by GEC (2006) for limestone formation is $3 \%$.

\section{Water resources development plan}

Water resource development plan has been prepared on the basis of integration of information on hydro geo-morphological characteristics, surface water availability, land use/cover, drainage, present status of ground water utilization and considering the present and long term needs of water in the study area. The present water availability in the micro watershed is presented in Table 1.

\section{Calculation of discharge of canal (Tar)}

The amount of water passing a point on the stream channel during a given time is a function of velocity and cross-sectional area of the flowing water.

$\mathrm{Q}=\mathrm{A} \times \mathrm{V}$

Where, $\mathrm{Q}$ is stream discharge $\left(\mathrm{m}^{3} / \mathrm{sec}\right)$, $\mathrm{A}$ is cross-sectional area $\left(\mathrm{m}^{2}\right)$ and $\mathrm{V}$ is flow velocity $(\mathrm{m} / \mathrm{sec})$.

\section{Velocity measurement}

Material required

tape measure

stop-watch

rod, yard or meter stick to measure depth

at least three highly visible buoyant objects such as a drifting branches or logs, pine cone, coffee stir sticks, half filled bottles, or oranges (objects buoyant enough not to be effected by the wind)

\section{Float method}

This method measures surface velocity. Mean velocity was obtained using a correction factor. The basic idea is to measure the time that it takes the object to float a specified distance downstream.

$\mathrm{V}_{\text {surface }}=$ travel distance $/$ travel time $=\mathrm{L} / \mathrm{t}$

The surface velocities are typically higher than mean or average velocities

$\mathrm{V}_{\text {mean }}=\mathrm{k} \mathrm{V}_{\text {surface }}$

Where, $\mathrm{k}$ is a coefficient that generally ranges from 0.8 for rough beds to 0.9 for smooth beds ( 0.85 is a commonly used value)

\section{Step 1}

Choose a suitable straight reach with minimum turbulence (ideally at least 3 channel widths long).

\section{Step 2}

Mark the start and end point of reach.

\section{Step 3}

If possible, travel time should exceed 20 seconds.

\section{Step 4}

Drop the object into the upstream of marker.

\section{Step 5}

Start the watch when the object crosses the 
upstream marker and stop the watch when it crosses the downstream marker.

\section{Step 6}

Repeat the measurement at least 3 times and use the average in further calculations.

\section{Step 7}

Measure stream's width and depth across at least one cross section where it is safe to wade.

\section{Surface runoff estimation}

Surface runoff of the watershed was estimated by using the SCS curve number method, also known as the Hydrologic Soil Cover Complex Method, developed by the Soil Conservation Service (SCS) of the U.S. Department of Agriculture for use in rural areas.

As per the developed runoff curve number by USDA, SCS the surface runoff was estimated by the equation:

$Q=\frac{(P-0.2 S)^{2}}{(P+0.8 S)}$

where, $\mathrm{Q}$ is the daily runoff $(\mathrm{mm}), \mathrm{P}$ is the daily rainfall $(\mathrm{mm}), \mathrm{S}$ is a retention parameter $(\mathrm{mm}), \mathrm{I}_{\mathrm{a}}$ is initial abstraction $(\mathrm{mm})$ during the period between the beginning of rainfall 1 and runoff in equivalent depth over the catchment, (taken as $0.3 \mathrm{~S}$ for most of the watersheds in India) and $S$ is the potential maximum retention $(\mathrm{mm})$. The value of $S(\mathrm{~mm})$ was calculated by using the following formula:

$S=2540 /\left(25.4+{ }^{C N}\right)$

$\mathrm{CN}$ is the curve number for average antecedent moisture condition (AMC) II which varies from 1 to 100 .

\section{Antecedent moisture conditions}

Antecedent moisture condition denotes the sum of proceeding 5 day's rainfall, to current day rainfall, for which the runoff is going to be estimated by curve number method. Antecedent moisture condition is considered as AMC-I, when the sum of previous 5 days rainfall is less than $36 \mathrm{~mm}$, it is considered as AMC-II, when it is between 36 to $53 \mathrm{~mm}$ rainfall, and it is under AMC-III when the sum of previous 5 days rainfall was greater than $53 \mathrm{~mm}$ during the growing season (monsoon period).

The available readymade tables gives curve number values for AMC-II, which was converted to the respective antecedent moisture condition AMC-I or AMC-II, prevailed in the watershed on the day in question.

\section{Runoff curve numbers}

The runoff curve numbers for monsoon seasons were worked out for hydrologic soil group - B. The present land use/cover was identified as paddy sown area, plantations, and settlements and vegetated land. For antecedent moisture condition II and $\mathrm{I}_{\mathrm{a}}=0.3 \mathrm{~S}$, the weighted curve number for watershed was obtained as 89.1 for hydrologic soil group B which was then converted to AMC-I and AMC-III and found as 77.5 and 96.1 respectively

\section{Calculation of curve number}

Volume of runoff $\left(\mathrm{m}^{3}\right)=$ Runoff $(\mathrm{mm}) \mathrm{x}$ Drainage area (ha) x 10 .

\section{Survey and mapping of the study area}

The survey of the study area was made first by moving around the area and marking out the physical features, which delineated its 
boundaries, based on some land demarcation points as given by old map and generated to contour map with the use of GIS arc map 10.

\section{Topographic survey}

After mapping the IGKV farm the next step taken was to conduct topographic survey in order to depict the relief or topography of the study area.

\section{Proposed of irrigation plan}

\section{Proposed lift irrigation plan}

Location of four Lift Irrigation Schemes to increase the utilization of available surface flows during Kharif season and Rabi season with their command area is shown in Fig. 3 Design discharge was calculated for Kharif season for LIS -1, LIS -2 and LIS -4, since water requirement of Rice is the highest among all the Kharif and Rabi crops. LIS- 3 is proposed for horticulture area. LIS- 1 is proposed to lift water from the pounding behind CD-1 whereas LIS-2 and LIS -3 are proposed on CD-2. LIS-4 is proposed to lift water from CD-3.

\section{Results and Discussion}

The results of the investigations made in IGKV farm Raipur,

\section{Surface water}

There are few surface water bodies and groundwater bodies being pumped in the study area. Surface water bodies are present in the form of tanks, flowing water in the adjacent stream being stored behind one of the tank locally called Bharri dam (T-1) and diverted through diversion works (locally called "Tar") to the university fields. Potential water availability in the form of surface runoff that could be harnessed has been assessed in the study.

\section{Water resource assessment}

The existing availability of water resources of the study area were worked out on the basis of data collected from AICRP on GWU project of SWE, IGKV Raipur. The results obtained through a systematic analysis are discussed.

\section{Surface water assessment}

Surface water use and surface water availability from existing surface water structures including surface runoff, is essential to assess the surface water component in this region. With the suitable method and on the availability of data same has been worked out. Runoff from study area

Volume of water available as runoff in the study area was worked out on the basis of depth of runoff calculated using SCS curve method as explained in chapter 3 the runoff was estimated as $353.3 \mathrm{~mm}$ for the study area. For the study area $(353.5 \mathrm{~mm})$ considering the land use land cover pattern of the study area.

Runoff volumes available $=0.3535 \mathrm{~m} \mathrm{X}$ 200 ha

$$
=70.7 \text { ha-m }
$$

\section{Capacity and command of diversion canal ("Tar")}

Longitudinal sections of the bed and bunds of diversion canal are shown in Figure 2 from the graph available grade were worked out to be $0.1 \%$. Bund height clearly shows that a space for maximum $60 \mathrm{~cm}$ pounding is available with a free board of $15 \mathrm{~cm}$. Calculations for arriving at the carrying capacity of diversion canal.

Calculations showed that carrying capacity of the diversion canal is 45.62 lps. Available flows through diversion canal were worked out by multiplying the discharge carrying 
capacity of the diversion canal by the number of probable canal operation days (75 days).

Available flows in canal

$0.04562 \mathrm{~m}^{3}$ x 75 days x $24 \mathrm{hr} \times 3600 \mathrm{sec}$

$$
\begin{aligned}
& =0.2956 \mathrm{Mm}^{3} \\
= & 29.56 \text { ha-m }
\end{aligned}
$$

\section{Surface water availability}

Total Available surface water = Volume available in water bodies/ Check Dams + Runoff volume available + Available flows in canal

$$
\begin{aligned}
& =16.203+70.7+29.56 \\
& =116.46 \text { ha-m }=1.165 \mathrm{Mm}^{3}
\end{aligned}
$$

\section{Net groundwater availability}

The net groundwater availability has been computed after deducting the natural discharge from the replenishable groundwater resources as per GEC norm. The net available groundwater was found to be $0.50 \mathrm{Mm}^{3}$.

\section{Longitudinal section}

This type of leveling is known as longitudinal sectioning. In high way, railway, canal or sewage line projects of the ground along selected routes are required. In such cases, along the route, at regular interval readings are taken and RL of various points are found. Then the section of the route is drawn to get the profile.

\section{Proposed irrigation plan}

Irrigation system of 4 LIS system will design 33.6 ha area of crop land with $0.62 \mathrm{MCM}$ volume of crop water requirement. Specifications of the proposed Lift Irrigation Schemes are the following table 2.

Average horse power of the submersible pumps of the study area

Total 26 Tube wells were irrigating the crops during Kharif

\section{Calculation of average pump capacity}

Total 11 submersible pumps are of $7.5 \mathrm{hp}$ capacity and 15 submersible pumps are of 5.0 hp capacity.

Hence average horsepower of the submersible pump has taken as

$$
\begin{aligned}
& =(7.5 \times 11+5 \times 15) / 26 \\
& =6.06 \mathrm{hp}
\end{aligned}
$$

Table.1 Water availability

\begin{tabular}{|l|c|}
\hline Water availability & in $\mathbf{M m}^{\mathbf{3}}$ \\
\hline Rainfall volume & 2.73 \\
\hline Runoff volume & 0.71 \\
\hline $\begin{array}{l}\text { Net ground water } \\
\text { available }\end{array}$ & 0.50 \\
\hline
\end{tabular}


Table.2 Specifications of the proposed Lift Irrigation Schemes

\begin{tabular}{|c|c|c|c|c|c|c|c|c|c|}
\hline \multirow[t]{3}{*}{ S. No. } & \multirow{3}{*}{$\begin{array}{l}\text { Command } \\
\text { (ha) }\end{array}$} & \multicolumn{4}{|c|}{ Pump specifications } & \multicolumn{4}{|c|}{ Pipe details } \\
\hline & & \multirow[t]{2}{*}{ Model No. } & \multirow{2}{*}{$\begin{array}{c}\text { Designed } \\
\text { discharge } \\
\text { (lps) }\end{array}$} & \multirow{2}{*}{$\begin{array}{c}\text { Total } \\
\text { head } \\
(\mathrm{m})\end{array}$} & \multirow{2}{*}{$\begin{array}{c}\text { Power } \\
\text { (hp) }\end{array}$} & \multicolumn{2}{|c|}{ Raising Main } & \multicolumn{2}{|c|}{ Distribution line } \\
\hline & & & & & & $\begin{array}{l}\text { Length } \\
\text { (m) }\end{array}$ & $\begin{array}{l}\text { Dia. } \\
(\mathrm{mm})\end{array}$ & Length (m) & $\begin{array}{l}\text { Dia. } \\
(\mathrm{mm})\end{array}$ \\
\hline LIS -I & 5.5 & KOS-341+* & 17.0 & 8 & 3 & 380 & 140 & 760 & 110 \\
\hline LIS -II & 9.4 & KOS-31* & 19.0 & 8 & 3 & 450 & 140 & 710 & 110 \\
\hline LIS -III & 12.5 & $\begin{array}{c}\text { KOS-520+ } \\
*\end{array}$ & 22.5 & 7.8 & 5 & 580 & 140 & 630 & 110 \\
\hline LIS -IV & 5.5 & KOS-341+* & 17.0 & 7.5 & 3 & 375 & 140 & 510 & 110 \\
\hline
\end{tabular}

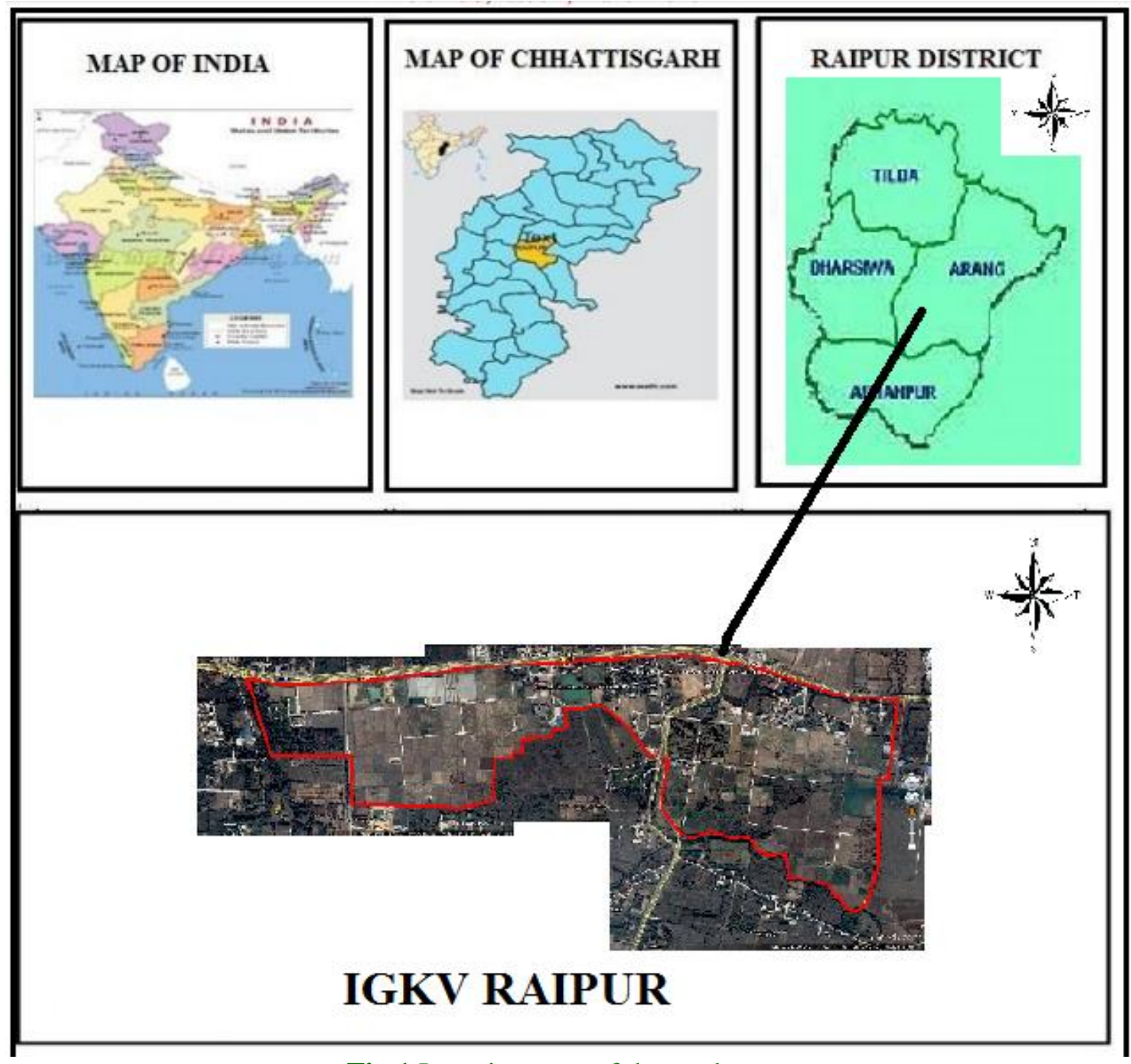

Fig.1 Location map of the study area 


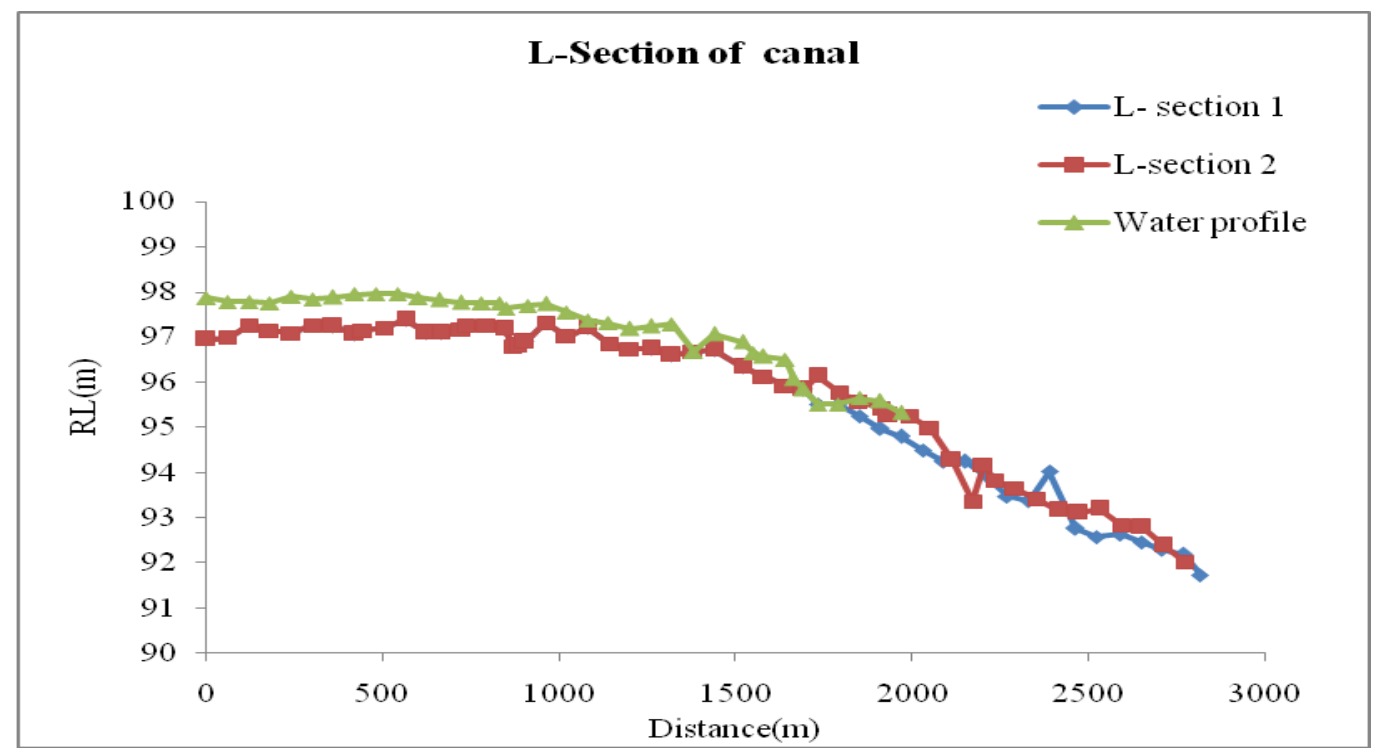

Fig.2 Section of diversion canal

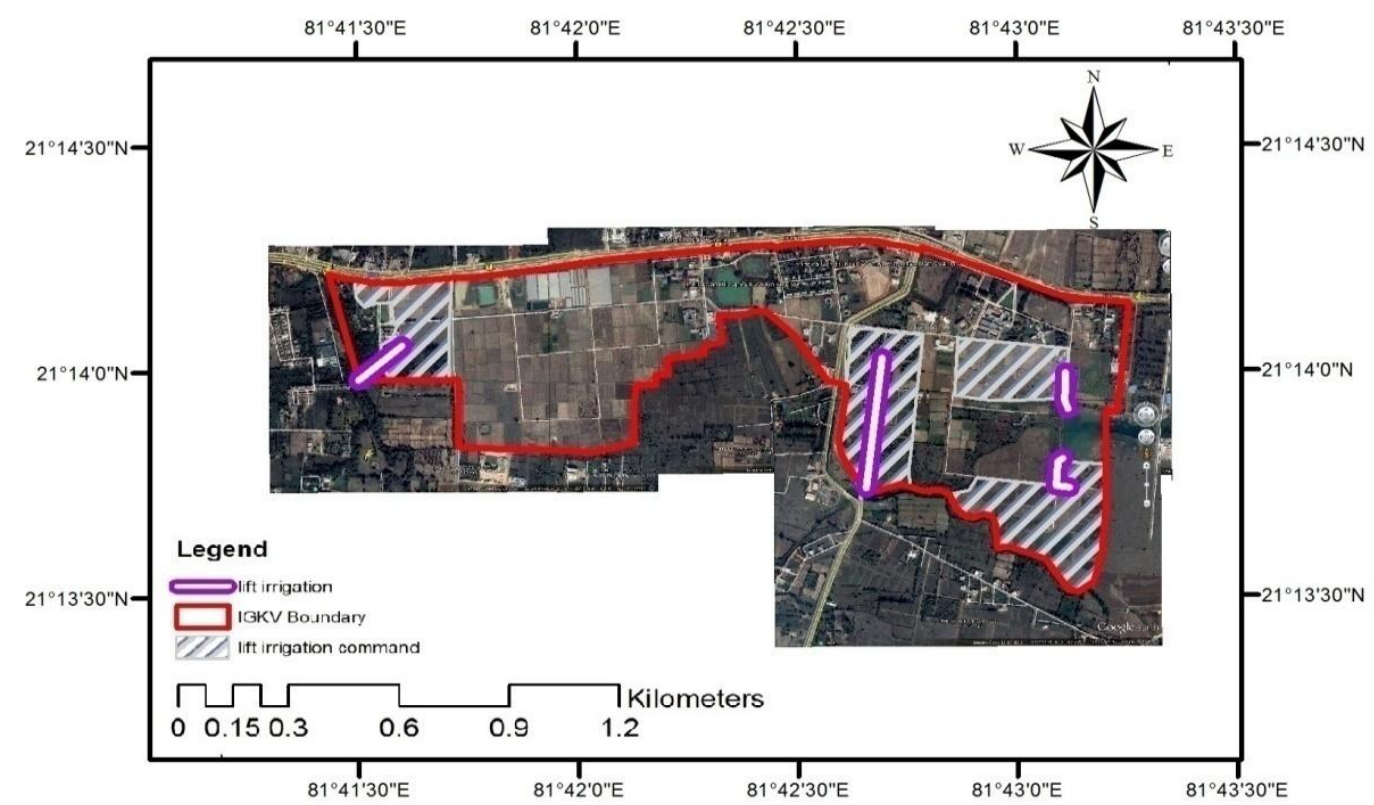

Fig.3 Proposed lift irrigation plan in study area

Irrigation plan of the study area was prepared successfully with the help of created resource map to relive the area from the water excess by utilizing the proposed drainage canals. Proposed irrigation plan will reduce the dependency of rapidly declining Ground water in the study area by utilizing the available surface flows.

\section{References}

Garg, S. K., (2009). Hydraulics and irrigation, Khanna Publishers, New Delhi.

Kumar, HR; Manjunatha, MV; Hebbara, M and Patil, G (2001). "Studies on the Performance of Sub-surface Drainage System in Saline Vertisols". Karnataka- 
J. Agric.-Sciences: 30-32

Lalonde, V; Madramootoo, CA; Trenholm, L and Broughton, RS (1995). "Effects of Controlled Drainage on Nitrate Concentrations in Subsurface Drainage Discharge". Agriculture Water Management, 29(2): 187-199.

Punmia, B. C. \& Pande, B. B. L. (2001). Irrigation and water engineering, Laxmi
Publications New Delhi.

Singh, DK (2006), "Design of Surface Drainage System" Training Manual Drainage Technology for Enhancing Agric. Productivity in Vertisols. CIAE Bhopal, : 77-88

Technical aspects for lift irrigation scheme, Vol -1 NABARDIS 4985

\section{How to cite this article:}

Thakur, N. K., D. Khalkho, P. Katre, P. K. Jamrey and Mishra, R. K. 2020. Design of Irrigation Network of the IGKV Farm, Raipur, Chhattisgarh, India. Int.J.Curr.Microbiol.App.Sci. 9(05): 1787-1795. doi: https://doi.org/10.20546/ijcmas.2020.905.202 